DOI: $10.31393 /$ reports-vnmedical-2021-25(4)-04

UDC: $616.517-055.1: 159.923$

\title{
PECULIARITIES OF EXPRESSION INDICATORS AND ACCENTUATED PERSONALITY TRAITS IN MEN WITH PSORIASIS WITHOUT TAKING INTO ACCOUNT SOMATOTYPE AND IN REPRESENTATIVES OF MESO- AND ENDO- MESOMORPHIC SOMATOTYPES
} Obadeh Bassam Abdel-Rahman Al-Qaraleh', Stepanenko V. I. ${ }^{2}$, Kryvonis T. G. ${ }^{1}$, Shkolnikov V. S. ${ }^{1}$, Prokopenko S. V. ${ }^{1}$

${ }^{1}$ National Pirogov Memorial Medical University, Vinnytsya (Pyrogov street, 56, Vinnytsya, Ukraine, 21018),

Bogomolets National Medical University, Kyiv (T. Shevchenko blvd., 13, Kyiv, Ukraine, 01601)

Responsible for correspondence: e-mail: dr.obadabassam@gmail.com

Received: July, 21, 2021; Accepted: August, 26, 2021

\begin{abstract}
Annotation. Exacerbation and aggravation of psoriasis increases the chances of neurosis, depression, can significantly impair mental health through social stigma and leads to social isolation and maladaptation, a significant reduction in quality of life. Studying this problem from the standpoint of comparative assessment of the distribution of character accentuations in patients with different dermatoses can provide insight into how a certain level of adequacy of psychological adaptive response is associated with organic pathological process or genetically existing expression of certain traits. The aim of the study was to found the features of indicators of expression and features of accentuated personality traits in men with psoriasis without taking into account somatotype and in representatives of meso- and endo-mesomorphic somatotypes. Men aged 22 to 35 years, patients with psoriasis ( $n=100$, including 32 with mild and 68 with severe course) at the Department of Skin and Venereal Diseases with a course of postgraduate education National Pirogov Memorial Medical University, Vinnytsya and Military Medical Clinical Center of the Central Region, conducted an anthropometric survey by V. V. Bunak Estimation of the expression and features of accentuated personality traits made according to G. Shmishek The reliability of the difference between the values between the independent quantitative values was determined using the U-Mann-Whitney test. In healthy subjects, taking into account and without taking into account the somatotype, it is seen that the type of physique did not significantly affect the severity of individual traits and their combinations in this group of people. With the increase in the course of psoriasis among subjects without somatotype, there is a decrease in the percentage of persons with hyperthymic and demonstrative and an increase - with emotional, pedantic, anxious, cyclothymic, excitable, dysthymic and exalted type of character accentuation; among patients of mesomorphic somatotype there is a decrease in the percentage of people with stuck and demonstrative and an increase - with emotional, pedantic, anxious, cyclothymic, excitable, dysthymic and exalted type of character accentuation; among patients of endo-mesomorphic somatotype there is a decrease in the percentage of people with hypertension and an increase - with stuck, demonstrative and excitable type of character accentuation. All this maintains a pathologically high level of affective tension, which disrupts the autonomic balance in the body, can be a pathogenic factor in the development of psychosomatic illness and leads to ineffective treatment of psoriasis.
\end{abstract}

Keywords: psoriasis, men, type of character accentuation, somatotype.

\section{Introduction}

Human skin is the outer covering of the body, which is considered in modern medicine as an independent organ that has many vital functions, including thermoregulatory, protective, respiratory, receptor, metabolic and others. One of the systemic diseases that is clearly manifested on the skin is psoriasis - a chronic immune-mediated disease with a complex multifactorial nature, which in terms of pathophysiology is manifested by abnormally high proliferation of keratinocytes and infiltration of immune cells in the dermis and dermis. Scientists have identified more than 70 loci associated with nuclear factor- $\mathrm{kB}$ and interferon signaling and the IL-23-IL-23 receptor axis as the genetic basis of the disease [5].

It should be noted that psoriasis is often accompanied by various comorbidities. For example, people with psoriasis often have cardiovascular disease (including myocardial infarction), obesity, hypertension, diabetes, metabolic syndrome, inflammatory bowel disease, non- alcoholic fatty liver disease, nephropathy, psoriatic arthritis and various mental disorders [18].

Excluding the cost of hospitalization, scientists estimate that a Malaysian with psoriasis spends more than $\$ 300$ a year to treat the disease. The prevalence of psoriasis in the world is quite high - about $2 \%$ of the world's population suffers from this disease [19].

In the United States, the prevalence of psoriasis is 3.1 $\%$, or 7.7 million people over the age of 20 . In particular, the heterogeneity of its distribution among different ethnic and racial groups within the studied sample, and different impact on everyday life depending on the severity of the disease [7].

Particular attention should be paid to the fact that patients with psoriasis are more at risk of various mental disorders. Analysis of the indicators of a large sample of patients with psoriasis and healthy individuals revealed that the risk is higher in the former $(5.13 \%$ vs. $4.07 \%$; $p=0.0001$; risk 
factor $=1.25 ; \mathrm{p}=0.0001)$, in particular it concerned anxiety disorders $(1.81 \%$ vs. $1.35 \% ; p=0.0048$; risk factor $=1.32$; $\mathrm{p}=0.0045)$ and depression $(3.01 \%$ vs. $2.42 \% ; \mathrm{p}=.0036$; risk factor $=1.25 ; p=0.0053$ ) [10].

Symptoms of the disease that concern patients also affect performance and, consequently, productivity. The severity of itching and pain adversely affect the physical and psychological health of patients, and together with increased peeling are reasons for skipping work and reducing their ability to work [11].

There is still no consensus among scientists on the impact of psoriasis on the risk of suicidal behavior. For example, in a 2020 study of nearly 170,000 psoriasis patients and 170,000 healthy individuals, statistical processing of the data found no association between the presence of the disease and the risk of suicidal behavior. In addition, no such association was found in different severity groups of patients, with or without complications [21].

In Ukraine, research on the relationship between constitutional indicators and indicators of personality characteristics has not yet become widespread [1], but encouraging results have been found in studies of the relationship between dermatoglyphic indicators and indicators of human personality $[6,15]$.

The aim of the study was to found the features of indicators of expression and features of accentuated personality traits in men with psoriasis without taking into account somatotype and in representatives of meso- and endo-mesomorphic somatotypes.

\section{Materials and methods}

Men aged 22 to 35 years, patients with psoriasis $(n=100$, including 32 with mild and 68 with severe) at the Department of Skin and Venereal Diseases with a course of postgraduate education National Pirogov Memorial Medical University, Vinnytsya and Military Medical clinical center of the Central region, conducted an anthropometric survey on V. V. Bunak [2]. The somatotype was calculated according to the mathematical scheme of $\mathrm{J}$. Carter and B. Heath [3].

Assessment of the severity and features of accentuated personality traits by G. Shmishek [4].

Statistical processing was performed in the license package "Statistica 5.5" using non-parametric evaluation methods. The reliability of the difference between the values between the independent quantitative values was determined using the U-Mann-Whitney test.

\section{Results. Discussion}

It is established that patients with psoriasis are characterized by both asymptomatic course and rich clinical picture. The disease varies in severity from small localized areas to lesions of the whole body. Eventually, in most patients, psoriasis affects the fingernails and toenails, causing dents, discoloration, yellowing, and so on. Skin injuries can cause psoriatic plaques in the irritated area $[13,17]$.

Dermatosis increases the chances of developing neurosis, depression, can significantly impair mental health through social stigma and leads to social isolation and maladaptation. A significant decrease in the quality of life in exacerbations of psoriasis has been established [8, 14]. However, the literature does not provide sufficient data on the study of the dependence of the diversity of clinical symptoms on the degree of accentuation of character (ie, strong expression of the main character traits) of patients.

To identify the relationship between the severity of clinical manifestations and the type of accentuation of the character of patients with psoriasis, all subjects underwent subjective and objective clinical examination, conducted a survey on the questionnaire Shmishek.

The percentage of people with no accentuation of character by the stuck type is significantly $(p<0.05)$ lower in patients with severe psoriasis $(39.71 \%)$ compared with patients with mild dermatosis $(62.50 \%)$. The percentage of persons with a tendency to develop character accentuation by excitable type is significantly $(p<0.05)$ higher in patients with severe psoriasis (55.88\%) compared with patients with mild dermatosis (34.38\%).

The percentage of people with a tendency to develop character accentuation by emotional type tends $(p=0.093$ $0.094)$ to higher values in patients with mild psoriasis $(50.00 \%)$ compared with patients with severe dermatosis $(32.35 \%)$ and the control group (32.93\%).

The percentage of people with no accentuation of character by the pedantic type tends $(p=0.069-0.094)$ to higher values in patients with mild psoriasis $(75.00 \%)$ and compared with patients with severe psoriasis $(55.88$ $\%)$ and the control group (57.32\%). The percentage of people with a tendency to develop accentuation by the pedantic type tends $(p=0.083)$ to lower values in patients with mild psoriasis $(21.88 \%)$ compared with the control group (39.02\%).

The percentage of people with no accentuation of character by anxiety type was significantly $(p<0.05)$ higher in patients with mild psoriasis $(96.88 \%)$ compared with patients with severe psoriasis $(82.35 \%)$ and the control group $(76.83 \%)$. The percentage of people with a tendency to develop accentuation by this type is significantly $(\mathrm{p}<0.05-$ $0.001)$ higher in healthy subjects $(21.95 \%)$ compared with patients with mild $(3.13 \%)$ and severe $(1.47 \%)$ course of psoriasis. The percentage of people with anxiety accentuation by anxiety type was significantly $(p<0.05-0.01)$ higher in men with severe psoriasis (14.71\%) compared with patients with mild dermatosis $(0 \%)$ and healthy subjects $(1.22 \%)$.

The percentage of people with no accentuation of character by cyclothymic type was significantly $(p<0.05-$ $0.001)$ higher in patients with mild psoriasis $(87.50 \%)$ compared with patients with severe psoriasis $(66.18 \%)$ and the control group (53.66 \%). The percentage of persons 
with a tendency to develop accentuation by this type is significantly $(p<0.01)$ higher in patients with mild dermatosis $(9.38 \%)$ compared to healthy individuals $(35.37 \%)$ and tends $(\mathrm{p}=0.072)$ to higher values compared with patients with severe psoriasis $(25.00 \%)$.

The percentage of persons with no accentuation of character by excitable type was significantly $(p<0.05)$ higher in patients with mild psoriasis $(78.13 \%)$ compared with the control group (54.88\%). The percentage of people with a tendency to develop accentuation by this type is significantly $(p<0.05)$ higher in healthy people $(37.80 \%)$ compared with patients with mild $(15.63 \%)$ and severe $(22.06 \%)$ course of psoriasis.

The percentage of persons with dysthymic type accentuation was significantly $(p<0.05)$ higher in men with severe psoriasis $(7.35 \%)$ compared to healthy subjects (0\%).

The percentage of people with exalted character by exalted type was significantly $(p<0.05)$ lower in men with mild psoriasis $(0 \%)$ compared to healthy subjects $(14.63$ $\%)$.

According to the indicator of accentuation of the character of hyperthymic and demonstrative, excitable type, no significant differences and tendencies of differences were found between different groups of subjects.

The percentage of people with no accentuation of character by the stuck type tends $(p=0.055)$ to higher values in male mesomorphs with mild psoriasis (60.71\%) compared to male mesomorphs with severe dermatosis $(38.18 \%)$. The percentage of people with a tendency to develop accentuation by this type tends $(p=0.059)$ to lower values in male mesomorphs with mild psoriasis (35.71\%) compared to male mesomorphs with severe dermatosis $(58.18 \%)$.

The percentage of people without emotional accentuation tends $(p=0.083)$ to lower values in male mesomorphs with severe psoriasis $(58.18 \%)$ compared to male endomesomorphs with similar disease course $(88.89 \%)$.

The percentage of people with a tendency to develop character accentuation by the pedantic type is significantly $(\mathrm{p}<0.05)$ higher in healthy mesomorphs $(48.72 \%)$ compared to healthy male endo-mesomorphic $(15.38 \%)$ and tends $(p=0.054)$ to higher values compared to patients with a mild course of the same somatotype $(25.00 \%)$. The percentage of people with a tendency to develop accentuation by the pedantic type tends $(\mathrm{p}=0.086-0.056)$ to lower values in healthy mesomorphs $(0 \%)$ compared to healthy men endomesomorphic $(7.69 \%)$ and compared to patients with severe disease of the same somatotype (9.09\%).

The percentage of people without character accentuation by anxiety type was significantly $(p<0.05)$ higher in mesomorphs with mild psoriasis $(96.43 \%)$ compared with mesomorphs with severe psoriasis $(80.80 \%)$ and healthy representatives of this somatotype $(74.36 \%)$. The percentage of people with a tendency to develop accentuation by this type is significantly $(p<0.05)$ higher in healthy mesomorphs $(25.64 \%)$ compared to mesomorphs with mild $(3.57 \%)$ and severe $(1.83 \%)$ course of psoriasis. The percentage of people with anxiety type accentuation was significantly $(p<0.05)$ higher in mesomorphs with severe psoriasis (16.36\%) compared to mesomorphs with mild disease course $(0 \%)$ and healthy mesomorphs $(0 \%)$.

The percentage of persons with no accentuation of character by cyclothymic type was significantly $(p<0.05-0.01)$ higher in mesomorphs of patients with mild psoriasis (89.29 $\%)$ compared with patients with severe course $(65.45 \%)$ and the control group (56.41\%) of the same somatotype. The percentage of persons with a tendency to develop accentuation by this type is significantly $(p<0.05)$ lower in patients with mild mesomorphs with mild dermatosis $(7.14 \%)$ compared to healthy persons with mesomorphs $(33.33 \%)$ and tends $(p=0.069)$ to lower values compared to patients with severe psoriasis $(23.64 \%)$.

The percentage of persons with no accentuation of character by excitable type was significantly $(p<0.05)$ higher in mesomorphs of patients with mild psoriasis $(78.57 \%)$ compared with the control group of the same somatotype $(51.28 \%)$. The percentage of people with a tendency to develop accentuation by this type was significantly $(p<0.05)$ higher in healthy people (43.59\%) compared with patients with mild (14.29 \%) and severe $(20.00 \%)$ course of psoriasis of mesomorphic somatotype.

The percentage of people with accentuation of character by exalted type was significantly $(\mathrm{p}<0.05)$ lower in male mesomorphs with mild psoriasis $(0 \%)$ compared to healthy subjects of the same somatotype (10.26\%).

According to the indicator of the accentuation of the character of the hyperthymic, dysthymic and demonstrative types, no significant differences and tendencies of differences were found between the different groups of the studied.

From the following distribution of types of accentuations in healthy subjects, taking into account and without taking into account somatotype, it is seen that body type did not significantly affect the expression of individual traits and their combinations in this group of people.

In the control group of subjects without taken into account somatotype, the following percentage distribution of types of accentuation was found: hyperthymic - in $37.80 \%$; stuck in $1.22 \%$; emotional - in $1.22 \%$; meticulous - $3.66 \%$; alarming - in $1.22 \%$; cyclothymic - in $10.98 \%$; demonstrative - in $3.66 \%$; exciting - in $7.32 \%$; dysthymic - in $0 \%$; of the exalted type - in $14.63 \%$.

The following percentage distribution of accentuation types was revealed in the control group of the studied mesomorphic somatotype: hyperthymic - in $38.46 \%$; stuck - in $0 \%$; emotional - in $0 \%$; meticulous - in $0 \%$; anxious - in $0 \%$; cyclothymic - in $10.26 \%$; demonstrative - in $5.13 \%$; exciting - in $5.13 \%$; dysthymic - in $0 \%$; exalted type - in 10.26 $\%$.

The following percentage distribution of accentuation types was found in the control group of endo-mesomorphic 
somatotype subjects: hyperthymic - in $23.08 \%$; stuck - in 0 $\%$; emotional - in $0 \%$; meticulous - in $0 \%$; anxious - in $0 \%$; cyclothymic - in $7.69 \%$; demonstrative - in $7.69 \%$; exciting in $7.69 \%$; dysthymic - in $0 \%$; exalted type - in $15.38 \%$.

Clinical studies have found that the level of anxiety and depression in patients with more severe dermatoses is much higher than in those with mild dermatoses [16, 20]. When using the Shmishek questionnaire, the most common types are identified: stuck, pedantic, cyclothymic, exalted, emotional. Taking into account the presented accentuations of character, patients have common psychological traits: boredom, formalism, hypersensitivity, vulnerability, suspicion, impulsiveness, frequent mood swings, severe failures and life cataclysms, periodic disability [9, 12, 12].

The following percentage distribution of accentuation types was found in subjects with mild psoriasis without taken into account somatotype: hyperthymic - in $40.63 \%$; stuck - in $3.13 \%$; emotional - in $0 \%$; pedantic - in $3.13 \%$; anxious - in $0 \%$; cyclothymic - in $3.13 \%$; demonstrative - in $6.25 \%$; exciting - in $6.25 \%$; dysthymic - in $0 \%$; exalted type - $0 \%$.

The following percentage distribution of accentuation types was found in subjects with severe psoriasis without taken into account somatotype: hyperthymic - in $36.76 \%$; stuck - in $2.94 \%$; emotional - in $4.41 \%$; pedantic - in $7.35 \%$; alarming - in $14.71 \%$; cyclothymic - in $7.35 \%$; demonstrative - in $4.41 \%$; exciting - in $10.29 \%$; dysthymic - in $7.35 \%$; of the exalted type - at $7.35 \%$.

The following percentage distribution of accentuation types was found in the subjects of mesomorphic somatotype with mild psoriasis: hyperthymic - in $39.29 \%$; stuck - in 3.57 $\%$; emotional - in $0 \%$; pedantic - in $3.57 \%$; anxious - in $0 \%$; cyclothymic - in $3.57 \%$; demonstrative - in $7.14 \%$; exciting in $7.14 \%$; dysthymic - in $0 \%$; exalted type - $0 \%$.

The following percentage distribution of accentuation types was found in the subjects of mesomorphic somatotype with severe psoriasis: hyperthymic - in $40.00 \%$; stuck - in $1.82 \%$; emotional - in $5.45 \%$; pedantic - in $9.09 \%$; alarming - in $16.36 \%$; cyclothymic - in $9.09 \%$; demonstrative - in 3.64 $\%$; exciting - in $10.91 \%$; dysthymic - in $7.27 \%$; exalted type in $9.09 \%$.

The following percentage distribution of accentuation types was found in the studied endo-mesomorphic somatotype with a mild course of psoriasis: hyperthymic - in $50.00 \%$; stuck - in $0 \%$; emotional - in $0 \%$; meticulous - in 0 $\%$; anxious - in $0 \%$; cyclothymic - in $0 \%$; demonstrative - in $0 \%$; excitable - in $0 \%$; dysthymic - in $0 \%$; exalted type - $0 \%$.

\section{References}

[1] Andriievskyi, I. I., Serebrennikova, O. A., Kyrychenko, I. M., Zhuchenko, I. I., \& Gunas, V. I. (2020). Correlations of body structure and size indicators with personality indicators of practically healthy women with mesomorphic somatotype. Biomedical and Biosocial Anthropology, (39), 35-44. doi: 10.31393/bba39-2020-06

[2] Bunak, V. V. (1941). Antropometriia [Anthropometry]. M.: Narkompros RSFSR - M.: People's Commissariat of the RSFSR.

[3] Carter, J. L., \& Heath, B. H. (1990). Somatotyping - development and applications. Cambridge University Press.
The following percentage distribution of accentuation types was found in the subjects of endo-mesomorphic somatotype with severe psoriasis: hyperthymic - in $22.22 \%$; stuck - in $11.11 \%$; emotional - in $0 \%$; meticulous - in $0 \%$; anxious - in $0 \%$; cyclothymic - in $0 \%$; demonstrative - in $11.11 \%$; exciting - in $11.11 \%$; dysthymic - in $0 \%$; exalted type $-0 \%$.

Thus, with the increase in the severity course of psoriasis among the subjects without taken into account somatotype, there is a decrease in the percentage of persons with hyperthymic and demonstrative and increase - with emotional, pedantic, anxious, cyclothymic, excitable, dysthymic and exalted type of character accentuation; among mesomorphic patients there is a decrease in the percentage of people with stuck and demonstrative and an increase with emotional, meticulous, anxious, cyclothymic, excitable, dysthymic and exalted type of character accentuation; among endo-mesomorphic patients there is a decrease in the percentage of people with hypertensive and an increase with stuck, demonstrative and excitable type of character accentuation. All this maintains a pathologically high level of affective tension, which disrupts the autonomic balance in the body, can be a pathogenic factor in the development of psychosomatic illness and leads to ineffective treatment of psoriasis.

\section{Conclusions and prospects for further development}

1. With the increase of severity course of psoriasis there is an increase in the percentage of people with emotional, pedantic, anxious, cyclothymic, excitable, dysthymic and exalted type of character accentuation (studied without taking into account somatotype and mesomorphs) and people with stuck, demonstrative and exciting type of character accentuation (endo-mesomorphs).

2 . The results indicate that the severity of clinical manifestations of dermatosis in subjects is closely related to their inherent type of character accentuation, which must be taken into account in a balanced approach to symptomatic therapy and addressing the activation of psychological rehabilitation at the stage of active drug therapy.

In further research, knowledge and consideration of the mechanisms of response to the disease can increase the effectiveness of the latter, help to choose the most precisely targeted methods of treatment.

[4] Eliseev, О. Р. (2017). Практикум по психологии личности: учеб. пособие для бакалавриата и магистратуры (4-е изд., перераб. и доп.) [Practicum on Personality Psychology: Study Guide for Bachelor's and Master's Degrees (4th edition, revised and enlarged)]. М.: Издательство Юрайт - Moscow: Yurayt Publishing House. ISBN 978-5-534-04901-5

[5] Greb, J. E., Goldminz, A. M., Elder, J. T., Lebwohl, M. G., Gladman, D. D., Wu, J. J., ... \& Gottlieb, A. B. (2016). Psoriasis. Nature Reviews Disease Primers, 2(1), 1-17. doi: 10.1038/ nrdp.2016.82 
[6] Gunas, V. I. (2019). Correlations of indices of personality traits with indexes of finger and palmar dermatoglyphics of practically healthy Ukrainian men. Biomedical and biosocial anthropology, (34), 20-25. doi: 10.31393/bba34-2019-03

[7] Helmick, C. G., Lee-Han, H., Hirsch, S. C., Baird, T. L., \& Bartlett, C. L. (2014). Prevalence of psoriasis among adults in the US: 2003-2006 and 2009-2010 National Health and Nutrition Examination Surveys. American journal of preventive medicine, 47(1), 37-45. doi: 10.1016/j.amepre.2014.02.012

[8] Hrehorow, E., Salomon, J., Matusiak, U., Reich, A., \& Szepietowski, J. C. (2012). Patients with psoriasis feel stigmatized. Acta dermato-venereologica, 92(1), 67-72. doi: 10.2340/00015555-1193

[9] Jaremka, L. M., Lindgren, M. E., \& Kiecolt-Glaser, J. K. (2013). Synergistic relationships among stress, depression, and troubled relationships: insights from psychoneuroimmunology. Depression and anxiety, 30(4), 288-296. doi: 10.1002/ da.22078

[10] Kimball, A. B., Wu, E. Q., Guerin, A., Andrew, P. Y., Tsaneva, M., Gupta, S. R., ... \& Mulani, P. M. (2012). Risks of developing psychiatric disorders in pediatric patients with psoriasis. Journal of the American Academy of Dermatology, 67(4), 651-657. https://doi.org/10.1016/j.jaad.2011.11.948

[11] Lewis-Beck, C., Abouzaid, S., Xie, L., Baser, O., \& Kim, E. (2013). Analysis of the relationship between psoriasis symptom severity and quality of life, work productivity, and activity impairment among patients with moderate-to-severe psoriasis using structural equation modeling. Patient preference and adherence, 7, 199-205. doi: 10.2147/ PPA.S39887

[12] Lim, D. S., Bewley, A., \& Oon, H. H. (2018). Psychological profile of patients with psoriasis. Ann Acad Med Singapore, 47(12), 516-522. PMID: 30636268

[13] Parisi, R., Symmons, D. P., Griffiths, C. E., \& Ashcroft, D. M. (2013). Global epidemiology of psoriasis: a systematic review of incidence and prevalence. Journal of Investigative Dermatology, 133(2), 377-385. doi: 10.1038/jid.2012.339
[14] Sampogna, F., Tabolli, S., \& Abeni, D. (2012). Living with psoriasis: prevalence of shame, anger, worry, and problems in daily activities and social life. Acta dermato-venereologica, 92(3), 299-303. doi: 10.2340/00015555-1273

[15] Serebrennikova, O. A., Gunas, V. I., Klimas, L. A., Ocheretna, N. P., \& Shayuk, A. V. (2019). Predictive assessment of the association of dermatoglyphic indicators with indicators of personality traits, established by factor analysis. Reports of Morphology, 25(1), 12-18. doi: 10.31393/morphology-journal2019-25(1)-02

[16] Slavich, G. M., \& Irwin, M. R. (2014). From stress to inflammation and major depressive disorder: a social signal transduction theory of depression. Psychological bulletin, 140(3), 774815. doi: $10.1037 / \mathrm{a} 0035302$

[17] Stepanenko, V. I., Chobotar, A. I., \& Bondar, S. O. (2015). Дерматологія і венерологія: підручник [Dermatology and venereology: a textbook]. Київ: ВСВ "Медицина" - Kyiv: VSV "Medicine". ISBN 978-617-505-384-3

[18] Takeshita, J., Grewal, S., Langan, S. M., Mehta, N. N., Ogdie, A., Van Voorhees, A. S., \& Gelfand, J. M. (2017). Psoriasis and comorbid diseases: epidemiology. Journal of the American Academy of Dermatology, 76(3), 377-390. doi: 10.1016/ j.jaad.2016.07.064

[19] Tang, M. M., Chang, C. C., Chan, L. C., \& Heng, A. (2013). Quality of life and cost of illness in patients with psoriasis in Malaysia: a multicenter study. International journal of dermatology, 52(3), 314-322. doi: 10.1111/j.13654632.2011.05340.x

[20] Tohid, H., Aleem, D., \& Jackson, C. (2016). Major depression and psoriasis: a psychodermatological phenomenon. Skin pharmacology and physiology, 29(4), 220-230. doi: 10.1159/ 000448122

[21] Wang, S. H., Wang, J., Chi, C. C., Lin, Y. S., Liao, S. C., Chen, P. E., \& Tung, T. H. (2020). Risk for suicidal behavior among psoriasis patients: A nationwide cohort study. American journal of clinical dermatology, 21(3), 431-439. doi: 10.1007/ s40257-019-00489-9

\section{ОСОБЛИВОСТІ ПОКАЗНИКІВ ВИРАЖЕНОСТІ ТА ОСОБЛИВОСТЕЙ АКЦЕНТУЙОВАНИХ РИС ОСОБИСТОСТІ У ХВОРИХ НА ПСОРІАЗ ЧОЛОВІКІВ БЕЗ УРАХУВАННЯМ СОМАТОТИПУ ТА ПРЕДСТАВНИКІВ МЕЗО- Й ЕНДО-МЕЗОМОРФНОГО} СОМАТОТИПІВ

Обадех Бассам Абдель-Рахман Аль-Каралех, Степаненко В. І., Кривоніс Т. Г., Школьніков В. С., Прокопенко С. В. Анотація. Загострення та поважчання перебігу псоріазу підвищує шанси розвитку неврозів, депресії, може значно погіриувати психічне здоров'я через суспільну стигматизацію та призводить до соціальної ізоляції і дезадаптації, суттєвого зниження якості життя. Вивчення цієї проблеми з позиції порівняльної оцінки розподілу акцентуацій характеру у хворих з різним перебігом дерматозу може дати розуміння того, наскільки визначений рівень адекватності психологічної адаптивної реакції пов'язаний з органічним патологічним процесом або з генетично існуючою виразністю окремих рис характеру. Мета дослідження - вивчити особливості показників вираженості та особливостей акцентуйованих рис особистості у хворих на псоріаз чоловіків без урахування соматотипу та у представників мезо- і ендо-мезоморфрного соматотипів. Чоловікам віком від 22 до 35 років, хворим на псоріаз ( $n=100$, серед яких 32 із легким перебігом і 68 із тяжким перебігом) на базі кафредри шкірних і венеричних хвороб з курсом післядипломної освіти Вінницького національного медичного університету ім. М. І. Пирогова та Військово-медичного клінічного центру Центрального регіону, проведено антропометричне обстеження за В. В. Бунаком. Оцінка вираженості та особливості акцентуйованих рис особистості за G. Shmishek. Cтатистична обробка проведена в ліцензійному пакеті "Statistica 5.5" із використанням непараметричних методів оцінки. Достовірність різниці значень між незалежними кількісними величинами визначено за допомогою U-критерія Мана-Уітні. У здорових досліджуваних з урахуванням і без урахування соматотипу видно, що тип тілобудови суттєво не вплинув на вираженість окремих рис характеру та ї комбінацій у даного контингенту осіб. При поважчанні перебігу псоріазу серед досліджуваних без урахування соматотипу відмічається зменшення відсоткової частки осіб із гіпертимним і демонстративним і збільшення - з емотивним, педантичним, тривожним, циклотимним, збудливим, дистимним і екзальтованим типом акцентуації характеру; серед пацієнтів мезоморфрного соматотипу відмічається зменшення відсоткової частки осіб із застрягаючим і демонстративним $i$ збільшення з емотивним, педантичним, тривожним, циклотимним, збудливим, дистимним і екзальтованим типом акцентуації характеру; серед пацієнтів ендо-мезоморфрного соматотипу відмічається зменшення відсоткової частки осіб із гіпертивним $і$ збільщення - із застрягаючим, демостративним і збудливим типом акцентуації характеру. Все це підтримує патологічно високий рівень афрективної напруженості, що порушує вегетативний баланс в організмі, може виступати патогенним фрактором розвитку психосоматичного захворювання та призводить до неефективності лікування псоріазу. Ключові слова: псоріаз, чоловіки, тип акцентуації характеру, соматотип. 